\title{
A BRIDGE OVER TROUBLED URBAN WATERS
}

\section{W. E. B. Du Bois's The Philadelphia Negro and the Ecological Conundrum ${ }^{1}$}

\author{
Marcus Anthony Hunter \\ Department of Sociology, Yale University
}

\begin{abstract}
Generating new understandings of the contributions of W. E. B. Du Bois's The Philadelphia Negro (1899) for sociology and social science more generally, this article posits that the urban analysis provided in the book demonstrates how interwoven cultural and economic factors undergird the social organization of urban communities more so than any pragmatic economic pattern or logic. It is the interwoven nature of these factors (defined in this article as the counterintuitive economic logics of the study) that have been insufficiently acknowledged in recent decades of social scientific urban studies research. Exploring the interwoven nature of cultural and economic factors in the sustenance of Philadelphia's Black Seventh Ward, this article suggests that the agency of African Americans is a critical, yet undervalued, aspect of their urban living. This article situates W. E. B. Du Bois as the first of some later voices (mostly within urban ethnography) that offer a corrective and alternative to urban spatial conceptual frameworks that did not and do not fully account for the persistent influence of race and the agency of racial minorities on the landscape of American cities.
\end{abstract}

Keywords: W. E. B. Du Bois, The Philadelphia Negro, Urban America, Race, Black Agency, Ecological Conundrum, Urban Research, Black Seventh Ward

In Philadelphia, as elsewhere in the United States, the existence of certain peculiar social problems affecting the Negro people are plainly manifest. Here is a large group of people-perhaps forty-five thousand, a city within a city-who do not form an integral part of the larger social group.

—W. E. B. Du Bois, The Philadelphia Negro (1899, p. 5; emphasis added)

\section{INTRODUCTION}

The noise of pots clanging, dishes dropping, the food cooking, and the idle chatter of the hungry were the likely sounds that followed a young man and his wife as they 
sought refuge in their quaint quarters located at 700 Lombard Street in the heart of Philadelphia's Black Seventh Ward in the fall of 1896. The young man, a burgeoning Black scholar named William Edward Burghardt (W. E. B.) Du Bois, and his new wife, Nina, dropped their belongings to the floor just above the local cafeteria likely looking around to take their first deep breath in their new home. It had been a bit of journey for the Du Boises, having traveled to Philadelphia from Wilberforce, Ohio and their hopes were high for the potential prosperity the move from rural Ohio to urban Pennsylvania represented (Du Bois 1967).

Much like many Black Americans in the late nineteenth century, the Du Boises' arrival in Philadelphia was not an accident. The Du Boises, like scores of Blacks in the wake of Emancipation and Reconstruction, sought new opportunities that urban northern cities such as Philadelphia, New York City, and Boston seemed to hold in store for them. While Du Bois (1967) differed from the average Black migrant during this period, having received his $\mathrm{PhD}$ from Harvard University just a few years prior, he was not unlike them in that Philadelphia for him represented an opening in the "door of opportunity ... just a crack, to be sure, but a distinct opening" (p. 192). The opportunity which had called him from rural Ohio, was from Samuel McCune Lindsay a White sociologist and professor at the University of Pennsylvania, requesting that Du Bois (1967) come out and take up a year-long study of "the Philadelphia Negro" and the myriad problems believed to be endemic to this segment of Philadelphia's population.

Often dressed in a sharp, well-fitted suit, Du Bois was dapper and took his job seriously. He knocked on the doors of the various row homes along Lombard and South Streets inhabited by Black Seventh Warders, conducted interviews, and wrote in a daily journal to keep track of everyday life in the neighborhood. The Black Seventh Ward, while anchored by the hopes, dreams, and aspirations of Black families such as the Du Boises, was no easy place to live. Du Bois (1967) described the environment surrounding his small room at 700 Lombard as a dangerous one with "an atmosphere of dirt, drunkenness, poverty, and crime," adding "[m] urder sat at our doorsteps, police were our government, and philanthropy dropped with periodic advice" (p. 195). It would, however, provide him with a social scientific laboratory rife with the social ills, disputes, conflicts, and possibilities that he would channel a year later into a book aptly titled The Philadelphia Negro: A Social Study published in 1899 by the University of Pennsylvania Press.

In the book, Du Bois charged that the problems of the Philadelphia Negro were mere symptoms of the years (centuries for that matter) of prejudice, enslavement, and discrimination under which Black Americans had lived for so long. He charged both Black and White Philadelphians, specifically, and Americans, more generally, with the combined duty to enact a series of changes that would help provide access and resources (social, economic, and political) to the Philadelphia Negro. However important and powerful such a proclamation was, it would largely fall on deaf ears, and when the post at the University of Pennsylvania did not manifest into something more permanent, the Du Boises packed up and left Philadelphia. No longer a Philadelphia Negro, Du Bois would later follow up his ideas and observations in The Philadelphia Negro from his new intellectual hub at Atlanta University in Georgia.

Long before scholars such as Robert Park (1915), St. Clair Drake and Horace Cayton (1945), William Julius Wilson (1987, 1996), and Douglas Massey and Nancy Denton (1993) (to name a few), imagined ethnic and racial urban enclaves as comprising entities unto themselves, Du Bois (1899) characterized urban Black enclaves as "a city within a city" (p. 5). Employing and examining this spatial concept, Du Bois's The Philadelphia Negro provides an oft-overlooked analytic bridge between the 
varied directions taken by urban scholars. Emphasizing the persistent impact of race, historically and contemporarily, Du Bois's analysis offers a path to examine the spatial organization of urban America.

To be sure, we find this phrase - "a city within a city" - along with various derivatives, ever-present in urban scholarship and research (Drake and Cayton, 1945; Silver and Moeser, 1995; Wilson 1987, 1996; Zorbaugh 1929). While notions of a "city within a city" have come to have a variety of meanings, including the idea that the city is a sort of habitat that shifts as people change and adapt to the physical, political, and socioeconomic environs, Du Bois's conception necessarily emphasizes the ways in which race, agency, and counterintuitive economic logics underpin the organization of racial urban enclaves such as the Black Seventh Ward. Thus, Du Bois identifies an alternative explanation or analytic bridge to examine and understand urban America.

Indeed, much of what distinguishes Du Bois's "city within a city" concept from those of others is that it begins with identifying and then explaining an ecological conundrum - the lack of employment opportunities for Black Philadelphians despite the proximity of their neighborhood to the city's economic core. In this article, I examine the key ideas that animate Du Bois's urban approach thus foregrounding a bridge to existing models for understanding urban growth, urban change, and the racial geography of urban America. Ultimately, I argue that if we look to Du Bois's The Philadelphia Negro beyond its descriptive virtues, we can began to tap into and exploit another important legacy and sociological insight embedded in the text. Whereas conventional notions of urban ecology suggest a city's economic core as the major organizational mechanism in urban America, Du Bois's model suggests the inverse. That is, the geography of opportunity (cultural, political, economic or otherwise) is tied to the racial geography of the city, fostering unevenness in the location and distribution of opportunity and residents. A hidden virtue of The Philadelphia Negro, then, is its capacity to depict the agency of African Americans in constructing institutions, social relations, and other resources that result in the social community that is formed for them in the seventh ward of Philadelphia. In this way, then, this article situates W. E. B. Du Bois as the first of some later voices (mostly within urban ethnography) that offer a corrective and alternative to urban spatial conceptual frameworks that did not/do not fully account for the persistent influence of race and the agency of racial minorities on the landscape of American cities.

\section{THE PHILADELPHIA NEGRO AND THE ECOLOGICAL CONUNDRUM}

The Black Seventh Ward was "in the centre of the city, near places of employment for the mass of people and near the centre of social life," leading people to "crowd here in great numbers" (Du Bois 1899, p. 290). Yet while the Black population was highly concentrated near the business center of the city, most were unable to garner employment in the business center. In fact, only $8.2 \%$ of its Black residents held industrial employment in 1898, despite the city's thriving industrial economy (Du Bois 1899; Katz and Sugrue, 1998). This fact presented a puzzle for Du Bois, referred to here as an ecological conundrum. Du Bois observed a concentration of urbanites living adjacent to but not being employed within the city's economic center. Observing this condition, Du Bois likely asked himself: "If employment is not the purpose of the Black settlement being so close to the economic center of the city, then why are Blacks concentrated in the Seventh Ward?" In grappling with this ecological conundrum, Du Bois provides a two-tiered urban approach that uses racial 
history and Black agency (i.e., boundary work, and developing and maintaining indigenous institutions) to demonstrate the limitations of a free-market and ecologicalbased understanding of the racial and ethnic geography of urban America.

Alluding to the multiple purposes of the book, Du Bois's biographer David Levering Lewis (1993) argues that in The Philadelphian Negro Du Bois "tended to understate [his] major premises, inserting them unobtrusively between data and analysis" (p. 202). As Lewis (1993) rightly observes, during the period within which The Philadelphia Negro was produced Du Bois (1899) sought "to gain the widest and most respectful hearing possible" and as such "must have calculated that it would be necessary to write what amounted almost to two books in one-one that would not be immediately denounced or ridiculed by the arbiters of mainstream knowledge, influence, and order for its transparent heterodoxy; and a second one that would, over time, deeply penetrate the social sciences" (p. 189). As Figure 1 shows, in the "Table of Contents" Du Bois continually emphasizes notions of the "city" alongside each of his discussions of empirical data covering the socioeconomic realities of Blacks and Whites in Philadelphia.

Lewis's observation, also, then reveals Du Bois's sociological analysis as a layered and embedded one. Lewis's assertion is important not only because it highlights Du Bois's disposition during the time he produced The Philadelphia Negro, but also

\section{TABLE OF CONTENTS.}

\section{THE PHILADELPHIA NEGRO.}

\begin{tabular}{|c|c|}
\hline Chapter I. The Scope of This Study & $r-4$ \\
\hline I. General aim & I \\
\hline 2. The methods of inquiry & I \\
\hline 3. The credibility of the results & 2 \\
\hline Chapter II. The Problem & $5-9$ \\
\hline 4. The Negro problems of Philadelphia & 5 \\
\hline 5. The plan of presentment & 8 \\
\hline Chapter III. The Negro in Philadelphia, $\mathrm{r}_{3} 8-\mathrm{r} 82 \mathrm{O}$ & $10-24$ \\
\hline 6. General survey & Io \\
\hline 7. The transplanting of the Negro, $1638-1760$ & II \\
\hline 8. Emancipation, $1760-1780$ & 15 \\
\hline 9. The rise of the freedmen, $1780-1820$ & 17 \\
\hline Chapter IV. The Negro in Philadelphia, 1820-1896 & $25-45$ \\
\hline ro. Fugitives and foreigners, $1820-1840$ & 25 \\
\hline II. The guild of the caterers, $1840-1870$ & 32 \\
\hline I2. The influx of the freedmen, $1870-1896$ & 39 \\
\hline Chapter V. The Size, Age and Sex of the Negro & \\
\hline Population & $46-65$ \\
\hline 13. The city for a century & 46 \\
\hline r4. The Seventh Ward, 1896 & 58 \\
\hline Chapter VI. Conjugal Condition & $66-72$ \\
\hline 15. The Seventh Ward & 66 \\
\hline 16. The city & 70 \\
\hline Chapter VII. Sources of the Negro Population & $73-82$ \\
\hline I7. The Seventh Ward & 73 \\
\hline 18. The city & 80 \\
\hline
\end{tabular}

Fig. 1. The Philadelphian Negro Table of Contents. 
because it points to the enduring social scientific legacy Du Bois's The Philadelphia Negro was to embody. Recent work on Du Bois's analysis in The Philadelphia Negro has begun to reveal some of the other elements included within this text including the longstanding German influence on Du Bois's sociological imagination (Anderson 1999; Bay 1998; Weger 2009; Young and Deskins, 2001; Zuberi 2004), his pioneering efforts in methods of ethnographic triangulation (Anderson 1999; Morris and Ghazani, 2005; O’Connor 2009) and demography (Bobo 2000; Wortham 2009), analyses of race relations in urban America (Aptheker 2000; Broderick 1974; Hunter 2013; Marable 1986; McKee 1993; Morris 2006; Rudwick 1974; Watts 1983; Wright 2000), and his significant discussion of assimilation patterns of immigrants and migrants (Drake and Cayton, 1945; Wortham 2008). Despite the new insights afforded by recent research, honing in on Du Bois's notion of a "city within a city" affords new insights into the book, and squarely places him and The Philadelphia Negro into a long-standing dialogue and debate regarding urban Black enclaves, spatial inequality, and urban racial relations.

As will be shown, Du Bois's arrival at the idea of the Black Seventh Ward as constituting an "urban island" required a cultural-historical analysis that in many ways presages those which were to follow, including notions of a "Black Belt" in Chicago (Drake and Cayton, 1945; Pattillo 2007), symbolic economies in cities like Orlando and New York (Zukin 1991, 1995), and cultural boundaries (Hunter 1982; Suttles 1970). Furthermore, Du Bois's analysis of the Black Seventh Ward and Philadelphia demonstrates that two factors are key to his conception of the city and patterns of urban change, the agency of Black urbanites, and race relations. Together, these factors figure prominently in Du Bois's explanation of the spatial organization of urban America and the residents therein.

\section{Race, Racial History and The Philadelphia Negro}

If the Black Seventh Ward is proximal to Philadelphia's employment sector, why are there high levels of Black underemployment and unemployment? Anticipating Park's $(1915,1983)$ ecological conception of the city, Du Bois's urban approach treats the city as a an historical artifact, whose "organic" organization is due to the history of the city's racial groups and their relationship to economic and political power in the city. Further, the influence of such racial history is sustained through the actions and attitudes of Black residents, which facilitate the creation of cultural institutions such as social clubs and churches that maintain boundaries of ethnic and racial separation within Philadelphia.

Highlighting the connection between the "Negro problem" and the ecological conundrum, Du Bois (1899) asserts: "the social student ... must point out that the removal of unpleasant features from our complicated modern life is a delicate operation" and is underscored by the theory "that to know the removable causes of the Negro slums of Philadelphia requires a study that takes one far beyond the slum districts" (p. 6). Devoting a significant portion of the text to the "difficult question of environment, both physical and social," Du Bois affirms that in The Philadelphia Negro he will elucidate a Du Boisian urban approach: "propos[ing] to describe, analyze, and so far as possible, interpret" (p. 8) the relationship between the city's racial geography and the ecological conundrum.

As Lewis (1993) suggests, in The Philadelphia Negro Du Bois (1899) spends the bulk of his discussion in most of the book's chapters laying out his empirical findings, leaving much of his urban approach and commentary on the city and its "organic life" (p. 284) alongside and often implicitly within the presentation of his findings. 
For example, we find elements of his urban approach within his discussion of the physical environment of Philadelphia and the neighborhood:

The Seventh Ward starts from the historic centre of Negro settlement in the city, South Seventh street and Lombard, and includes the long narrow strip, beginning at South Seventh and extending west, with South and Spruce streets as boundaries, as far as the Schuylkill River. The colored population of this ward numbered 3621 in 1860, 4616 in 1870, and 8861 in 1890. It is a thickly populated district of varying character; north of it is the residence and business section of the city; south of it a middle class and workingmen's residence section; at the east end it joins Negro, Italian and Jewish slums; at the west end, the wharves of the river and an industrial section separating it from the grounds of the University of Pennsylvania and the residence section of West Philadelphia (1899, p. 58).

This depiction of the physical boundaries of the Black Seventh Ward is important in that Du Bois highlights the complicated arrangement of the city's residents, revealing the vastness of the physical landscape despite the narrow space that Blacks inhabit, the spatial mismatch. Du Bois notes that the physical space inhabited by Black residents has continually deteriorated despite its central location and the larger prosperity of the city.

From growth in physical size, to the "increase in foreign population," to the "development of large industry and increase of wealth," to the large influx of migrant southern Blacks, Philadelphia was a urban ideal type, lending well to sociologically understanding cities such as Baltimore, Memphis, Richmond, Washington D.C., and Boston whose history mirrored its own (Du Bois 1899, p. 44). Functioning as a "natural gateway between the North and the South," the Black population of Philadelphia was the product of an "indirect" process of migration. In particular, Du Bois (1899) saw the racial geography of Philadelphia as also influenced by its relationship to other cities within a given region. While a portion of the Black community in Philadelphia was indigenous, most Black Philadelphians were southern migrants. Detailing the migration process involved in Blacks moving northward, Du Bois (1899) observes that many Black migrants would "come from country districts to small towns; then go to larger towns, eventually ... drift[ing] to Norfolk, Va, or Richmond . . . next . . to Washington, and finally . . . settl[ing] in . . Philadelphia" (p. 76).

Turning to an historical discussion of Philadelphia and the Black Seventh Ward, Du Bois identifies a more pronounced causal relationship between the ecological conundrum he observed and the factor he thought to be an explanatory key, racial history. While Du Bois (1899) focuses on several aspects of Philadelphia's history, particularly its Quaker origins and the establishment of the African Methodist Episcopal (A.M.E.) Church, it is in his discussion of the race riots of the 1830 s and $1840 \mathrm{~s}$ that he provides the clearest insight into the historical component of his urban approach:

In June and July, 1829, Mrs. Fanny Wright Daursmont, a Scotch woman, gave a number of addresses in Philadelphia, in which she boldly advocated the emancipation of the Negroes and something very like social equality of the races. This created great excitement throughout the city, and late in the fall the first riot against the Negroes broke out, occasioned by some personal quarrel. The Legislature had proposed to stop the further influx of Southern Negroes by making free Negroes carry passes and excluding all others (p. 27). 
The subsequent riots are critical because they lead to the eventual shape of the city and the concentration of Blacks in the Seventh Ward:

In 1833 a demonstration took place against the Abolitionists, and in 1834 serious riots occurred. One night in August a crowd of several hundred boys and men, armed with clubs, marched down Seventh street to the Pennsylvania Hospital. They were joined by others, and all proceeded to some places of amusement where many Negroes were congregated, on South Street, near Eighth. Here the rioting began, and four or five hundred people engaged in a free street fight. . . . The very next night the mob assembled again at Seventh and Bainbridge; they first wrecked a Negro church and a neighboring house, they attacked some twenty Negro dwellings. ... That the riots occurred by prearranged plan was shown by the signals_-lights in windows-by which the houses of the Whites were distinguished and those of the Negroes attacked and their inmates assaulted and beaten.... The next night the mob again assembled in another part of the city and tore down another Negro church. By this time the Negroes began to defend themselves in a building on Seventh street, below Lombard, where a howling mob of Whites soon collected. The mayor induced Negroes to withdraw, and the riot ended. In this three days' uprising thirty-one houses and two churches were destroyed and Stephen James "an honest, industrious colored man” killed (Du Bois 1899, pp. 27-28).

Following this historical description, Du Bois reveals that many key institutions in the Black Seventh Ward were rooted in such racial history emergent in the forty-year period following the riots.

Extending this discussion, Du Bois shows that churches such as Mother Bethel and St. Thomas A.M.E. were initially established as safe havens within the area providing protection to the Black population in addition to spiritual guidance. Many of the stores and businesses then emerged as the Black population and racial tensions persisted in the Black Seventh Ward (Du Bois 1899). In effect, then, Du Bois is suggesting that the institutional geography of the Black Seventh Ward is directly connected to the racial history of the Black Seventh Ward and Philadelphia. Observing that the location of many of the institutions, namely churches, hospitals and Black newspapers, were in response to the racial history of the city, Du Bois articulates the built environment of the Black and surrounding White community as a reflection of latent and lasting effects of the city's racial history. Racial history has organized Philadelphia, and the agency of its Black residents signals such history while also further facilitating the spatial dynamics it fostered.

By laying out the racial history of Philadelphia and its residents between the years 1638-1890, Du Bois conveys several key ideas. First, he provides historical context for the city and the people (particularly freed Blacks). Second, he provides a causal argument connecting the present condition of the city with the growth in racial tensions and rights/privileges of Blacks in the city. Third, with much detail, he explains the ebbs and flows of migration within and immigration to the city and the implications thereof. Finally, he provides historical details that are specific enough that they help in understanding the present-day Philadelphia, while also being general enough that they serve as representative for understanding "a great American city" (Du Bois 1899, p. 1). The last point is most critical as it underscores Du Bois's concern with generalizations while also demonstrating how he links urban spatial analysis with historical synthesis. Du Bois's urban approach, then, is one that con- 
ceptualizes the city's spatial organization as caused by racial historical events, namely those involving conflict.

Du Bois explicitly revisits this point in a later chapter, "The environment of the Negro." Demonstrating the lasting effects of the city's racial history, Du Bois highlights the continued racial practices in the city and how they affect the racial geography of the city. Du Bois (1899) asserts that much of the movement of Blacks in the city is determined by "the undeniable fact that most Philadelphia White people prefer not live near Negroes" thus limiting "very seriously ... his choice of home" (p. 295); thus discovering that urbanites also harbored neighborhood preferences that determined the racial geography of Philadelphia. Finding that interracial relations remained contentious despite the abolishment of slavery, Du Bois adds to his discussion of the importance of the city's racial history as a causal force. Discovering that employment opportunities alone do not explain the racial geography of residents in the city Du Bois (1899) observes:

[T] he mass of Negroes are purveyors to the rich-working in private houses, in hotels, larges stores etc. In order to keep this work they must live near by; the laundress cannot bring her Spruce street family's clothes from the Thirtieth Ward, nor can the waiter at the Continental Hotel lodge in Germantown. With the mass of White workmen this same necessity of living near work, does not hinder them from getting cheap dwellings; the factory is surrounded by cheap cottages, the foundry by long rows of houses, and even the White clerk and shop girl can ... live further out in the suburbs than the Black porter who opens the store (p. 296).

To be sure, Du Bois does account for the pay differential between Black and White workers as consequential, but only within the context of the enduring effects of the racial history of the city. What Du Bois depicts, then, is the lack of spatial mobility of urban Blacks and the racial geography of the city wherein both are significantly impacted by the city's racial history. Philadelphia, then, is depicted as a city that looks much like a chessboard, with densely populated Black areas, neighbored by densely populated White sections who often police the spatial mobility of Blacks through direct and indirect practices. Du Bois (1899), attributing the density of the Black center of the city and the "considerable crowding in the homes" within the Seventh Ward with the city's racial history, argues that such a history has in fact been a "very decisive hindrance to emigration to the suburbs" (p. 297).

In Du Bois's estimation, what remains, then, is a city whose racial geography is not explicitly market-driven, but instead the product of the racial history that he outlines early on in The Philadelphia Negro. While seemingly a commonplace observation, this point must be considered historically alongside the notion that Philadelphia was considered at the time a northern Quaker destination standing in direct opposition to the rigid and racist South. Du Bois, at the time, then offered a novel perspective positing that the city's racial history is significantly tied not only to the "Negro problem" but also to the urban landscape, even in a northern industrial city such as Philadelphia.

Essentially, Du Bois suggests that an understanding or examination of the urban environment cannot be separated from its history. Within Du Bois's discussion of the racial history of the city, he reveals his perspective to be one that sees the racial dynamic within a city as not just a historical fact but also a means for grounding his conception of the urban and explicating the ecological conundrum. Further the racial history for Du Bois implicitly links Philadelphia to other 
American cities, particularly northern destination cities such as Baltimore, New York City, and Boston. Ultimately, by positioning issues of race and history as operating principles within his approach, Du Bois's urban framework is one that privileges sociohistorical factors as having causal significance especially when examining and explaining the racial geography and general spatial organization of the city.

\section{Agency and The Philadelphia Negro}

To be sure, Du Bois's reliance on racial history could perhaps be viewed as deterministic, especially in its causal connections to present conditions. That is, in Du Bois's approach do the structural ramifications of racial history limit or dismiss the agency of urban residents inside/outside of the Black Seventh Ward and Philadelphia? Is his approach inherently teleological? In The Philadelphia Negro Du Bois appears cognizant of this possible critique and the embedded determinism of the racial historical component of his urban approach. Therefore, Du Bois incorporates a complementary component into his urban approach, Black agency. Indeed, the ecological conundrum Du Bois observes was both a historical fact and a contemporary reality.

In tandem, then, Du Bois's two-tiered urban approach focuses the agency of "the Philadelphia Negro," namely the culture and practices of Black urbanites and the institutions they establish and inhabit, particularly social clubs and churches. Whereas the historical component of Du Bois's urban approach perhaps privileges the agency of Whites and those in power to limit the location and expansion of the "city within a city," in my view his focus on the development of Black cultural and political institutions is meant to attend to and animate the important role of the agency of "the Philadelphia Negroes." In this way, Du Bois's second component presages recent research that has demonstrated the important role of social boundaries, and the agency of those who sustain and create such boundaries. For example, as Lamont and Molnár (2002) assert: "Social boundaries are objectified forms of social differences manifested in unequal access to and unequal distribution of resources (material and nonmaterial) and social opportunities" (p. 168). Neighborhood and racial boundaries require mutual reinforcement, from inside and on the outside, administrative and lived.

It is within his discussion of the "social environment," or contemporary cultural context that Du Bois (1899) expands on this second component of his urban approach, asserting: "the large influence of the physical environment of home and ward" notwithstanding, "there is a far mightier influence to mold and make the citizen, and that is the social atmosphere which surrounds him" (p. 309). As the riots occurred during the mid-1800's Du Bois argues that the Black population, especially "the better class of Negroes," sought refuge in Black institutions. Du Bois (1899) also observes that during these racially intense periods, attendance in Black schools increased as did attendance in "churches and benevolent societies" (p. 31). While rising to prominence during periods of racial conflict, cultural and indigenous institutions maintained a persistent and notable influence on the racial geography of the city.

Although the city's racial history precluded Blacks from moving into predominantly White areas, this historical narrative alone did not fully explain for Du Bois the continued spatial practices of Philadelphia's residents. Though Du Bois noted that race operated as an organizing principle with respect to the spatial landscape of the city, cultural and indigenous institutions such as churches, social clubs, and 
schools further influenced the movement of Black and White residents. Within Du Bois's conception of the city, Black and White spatial practices are distinctly linked, with Blacks often unable to move outward due to practices by White residents. Alongside such practices by Whites, indigenous institutions, centered in the Black Seventh Ward, limited within-city migration for Black residents. Focusing on the Black church, Du Bois (1899) asserts that the reason for concentration of Blacks:

[I]n certain localities is a social one and one peculiarly strong: The life of the Negroes of the city has for years centered in the Seventh Ward; here are the old churches, St. Thomas', Bethel, Central, Shiloh and Wesley; here are the halls of the secret societies; here are the homesteads of old families. To a race socially ostracised it means far more to move to remote parts of a city, than those who will in any part of the city easily form congenial acquaintances and new ties (p. 297).

In this discussion, Du Bois demonstrates that cultural institutions, namely Black churches, orient residents in light of the how the city's racial history has determined its racial geography.

In Du Bois's discussion of the Black church, such institutions are not just born out of the disenfranchisement of Blacks, but are also a cultural phenomenon that helps to fix individuals within urban space; thus sustaining the ecological conundrum. Du Bois (1899) argues that the "church is, to be sure, a social institution first, and religious afterwards” (p. 205). Du Bois, then, offers a nuanced perspective of the church, wherein it functions both as a religious and a spatial force within urban America.

Further, Du Bois posits cultural and indigenous institutions as key intervening forces within racially organized cities. As Du Bois (1899) observes: "Negro churches were the birthplaces of Negro schools and of all agencies which seek to promote the intelligence of the masses; and even to-day no agency serves to disseminate news or information so quickly and effectively among Negroes as the church" (p. 207). Du Bois, through this observation, shows that cultural and indigenous institutions within cities such as Philadelphia have a proximal relationship with residents and, most often, determine how and in what ways residents migrate into and move within the larger city. He asserts: "Each church forms its own social circle, and not many stray beyond its bounds. Introductions into that circle come through the church and thus the stranger becomes known" (p. 204); thus Du Bois points to a dialectical relationship between people and indigenous and cultural institutions in urban space.

Along this vein, Du Bois's discussion of Mother Bethel A.M.E. Church, founded by Black pastor Richard Allen, is especially instructive. Beginning as a "weekly gathering which met in Allen's Blacksmith shop" (1899, p. 199) that often provided both spiritual guidance and a place to hide from the vicious attacks of Whites, Mother Bethel Church grew into the largest Black church in the city. The impact of this church was wide-reaching, helping to create the national Christian denomination of A.M.E. which "grew and spread until in 1890 the organization had 452, 725 members, 2481 churches and \$6,468,280 worth property" (Du Bois 1899, p. 199). Detailing the major functions of the church, Du Bois (1899) argues that an understanding of Mother Bethel and other Black religious institutions must go beyond a consideration of religion:

[The Black church's] tribal functions are shown in its religious activity, its social authority and general guiding and co-ordinating work; its family functions are 
shown by the fact that the church is a centre of social life and intercourse; acts as a newspaper and intelligence bureau, is the center of amusements-indeed, is the world in which the Negro moves and acts (p. 201).

Emergent from the racial history of the city, Du Bois's description of and argument about indigenous and cultural institutions, such as Mother Bethel, reveals that while many of these institutions are born out of such history, after being established these institutions then work to further affirm the racial geography of the city, inadvertently facilitating the ecological conundrum. As Du Bois demonstrates, Black institutions like Mother Bethel maintained physical and cultural boundaries between the "city within a city" and the larger city by preferring to wield influence and expand within the neighborhood, rather than expand (its physical size, and cultural and social influence) beyond the neighborhood.

While it is clear in Du Bois's (1899) analysis the Black church is the most significant of these cultural indigenous institutions, his discussion also captures other institutions such as secret orders and societies as "next to the church they are the most popular organizations among Negroes" (p. 224). It is important for Du Bois that issues of social class resonate as well. In considering the racial geography of the city, Du Bois saw variation in social class as important as it reveals how such indigenous institutions influence the spatial landscape of the city. Secret societies and orders, in particular, provided social outlets for "well-to-do" Blacks while also limiting their spatial mobility because of their need and reliance on the social relations these institutions fostered (Du Bois 1899, p. 203). For example, Du Bois (1899) notes that while mason groups, such as the Knights of Pythias, were important in the social life of Blacks, these social events that they hosted never extended beyond their headquarters located within the Black Seventh Ward. Despite poor housing conditions, high rents, and overcrowding, Du Bois observes that Blacks still continued to live in the densely populated areas such as the Seventh Ward with Whites living in surrounding areas.

Though seemingly curious, Du Bois asserts the importance of cultural and indigenous institutions to explain this empirical reality, an ecological conundrum. Asserting that the location of institutions such as churches and social clubs directly influences the density of the Black areas, Du Bois (1899) observes that in cases where "the Negro . . ventures away from the mass of his people and their organized life," he "finds himself alone, shunned and taunted, stared at and made uncomfortable." Further, Du Bois observes that "the Negro who ventures away" is only able to "make few new friends, for his neighbors however well-disposed would shrink to add a Negro to their list of acquaintances" (p. 297). Within Du Bois's urban approach cultural and indigenous institutions have both social significance and causal relevance as they also shape the urban landscape. Du Bois, then, further imbues the notion of an "urban chessboard" with additional imagery, wherein the spatial landscape, being a series of Black and White dense blocks, has indigenous institutions emanating outward from specific points within these racially specific blocks with network webs that tie and often bind residents to particular spaces in the city.

\section{A BRIDGE OVER TROUBLED URBAN WATERS}

We seldom study the condition of the Negro to-day bonestly and carefully. It is so much easier to assume that we know it all. Or perhaps, having reached conclusions in our minds, we are loth to have them disturbed by facts.

—W. E. B. Du Bois, The Souls of Black Folk (1903, p. 99) 
Let's begin by returning to the central question that provides the important epistemological pivot for Du Bois leading to identifying and querying the ecological conundrum: If the Black Seventh Ward is proximal to Philadelphia's employment sector, why are there high levels of Black underemployment and unemployment? Through a reinterpretation of The Philadelphia Negro, I demonstrate that in the book Du Bois presents an urban approach wherein racial history and Black agency are primary components of Du Bois's conception and analysis of the urban America vis-à-vis Philadelphia. Examining Du Bois's discussion of Philadelphia, this article suggests that both variations and similarities between Du Bois, his peers and recent scholarship, hinge on his early identification of an ecological conundrum and his use of Black agency, race and history to explicate urban America. ${ }^{2}$ Here, I discuss Du Bois's urban approach not as counter to existing approaches, but, instead, as offering an early perspective that bridges conceptions of race and urban space, foregrounding an intellectual foundation for key ideas regarding urbanization and urban Black enclaves (Drake and Cayton, 1945) such as racial residential segregation (Massey and Denton, 1993), social isolation (Wilson 1987, 1996), and many other related ideas often considered today as conventional wisdom. ${ }^{3}$

Identifying existing explanations of the city afforded through extant approaches, I highlight the benefits of Du Bois's urban approach by placing his framework into conversation with some of the more popular approaches in urban scholarship. Du Bois's reliance on the role of race, history, and Black agency shifts our general gaze both then and now. When we begin to imagine the urban Black populace, as heterogeneous and sometimes discordant, and all the while agentic, we can begin to determine the true relationship that urban minorities share with the city.

Like many urban Black neighborhoods, the Black Seventh Ward contained a vibrant and heterogeneous mix of Black residents; and such heterogeneity often collided with and was reduced by structural changes in cities over time. As Du Bois (1899) suggested in The Philadelphia Negro, the importance of such heterogeneity cannot be overstated: "[A]nd there is no surer way of misunderstanding the Negro or being misunderstood by him than by ignoring manifest differences of condition and power in the 40,000 Black people of Philadelphia" (p. 310). Although urban scholars have studied issues of race and the sociopolitical realities of urban Blacks, discussions of the agency of urban Blacks in the existing scholarship focus primarily on the myriad subcultural practices that often rail against normative behavioral practices and beliefs. For example scholars have posited varying concepts such as "street vs. decent" (Anderson 1990), "ghetto-related behaviors" (Wilson 1996), "collective efficacy" (Hannerz 1969; Sampson et al., 1997; Stack 1974), and "under-the-table" employment practices (Venkatesh 2006), to characterize the agency of urban minorities.

Although such concepts reveal important information regarding the neighborhood-level behaviors urban minorities employ to make sense of and negotiate structural, economic, and social issues in American cities, little attention is given to the interaction between these urban minorities' expressions of agency and larger processes of structural urban change thought to give rise to such agentic practices. ${ }^{4}$ As a result, recent debates and scholarship have privileged the role of the actions and attitudes of predominantly White power structures and residents, and situated urban Black agency as reactive and not proactive. Such a focus is at least partially the by-product of the many cases in which Whites represent the majority of the population of a given city and often disproportionately occupy key urban political and corporate positions. However, as American cities have increasingly become majority-minority (i.e., Memphis, Detroit, and New Orleans) and others such as Philadelphia consistently contain a Black population totaling nearly fifty percent, the 
need for a more comprehensive understanding of the significance of the agency of urban minorities cannot be overstated (Stoll 2004). ${ }^{5}$ Indeed, as a result of various events including White flight, suburbanization, and de-industrialization, America's cities have been and are being bequeathed to urban minorities.

Other research, too, has taken an approach that harkens to the analytic bridge Du Bois provides in The Philadelphia Negro, yielding important information about the social realities of urban Blacks. An array of scholars across a variety of fields including, Mitchell Duneier (1999), Sudhir Venkatesh (1999, 2006), Karyn Lacy (2007), Steven Gregory (1998), and Adolph Reed (1999) have shown in their analyses of Black neighborhoods the influence of the actions of Black residents, stakeholders, brokers or "middlemen," elites, and gentrifiers on patterns of neighborhood change (Pattillo 2007; Wilson and Taub, 2006). Employing a similar Black-centered approach, The Philadelphia Negro pinpoints the larger significance of urban Black agency for conceptions of urban development and neighborhood change.

Where other researchers have attributed White movement out of cities or White flight to patterns of neighborhood and urban change, Du Bois's approach provides a template for demonstrating and analyzing the impact of the actions and attitudes of urban minorities on the landscape of urban America. As in The Philadelphia Negro, the movement of Black residents has been seen as significant in existing urban research, but much of this discussion has focused on either the flow of southern migrants into northern cities from 1900-1960 (The Great Migration) or on the relationship between such movement and White flight. As Du Bois reminds, Black residents were and are not always encroaching on established White neighborhoods, but often developing Black neighborhoods whose boundaries are based upon racial histories and the actions and attitudes of its residents.

In this way, Du Bois provides an early assertion that bridges explanations of urban spatial relations that suggest that the actions and attitudes of urban Blacks matter, particularly as pertains to patterns of neighborhood and urban change over time. Du Bois's The Philadelphia Negro offers evidence that suggests that the process of forging a "Black community" impacts the structure of the city and urban change, and provides an important, though underutilized, window into the structural changes in urban America. In this way, the creation of a Black community is a reflection of urban Black residents confronting inequality in an effort to thrive and survive in urban America.

Along this vein, Du Bois (1899) offers the following in his concluding chapter of The Philadelphia Negro:

Two sorts of answers return to the bewildered American who asks seriously: What is the Negro problem? The one is straightforward and clear: it is simply this, or simply that, and one simple remedy long enough applied will in time cause it to disappear. The other answer is apt to be hopelessly involved and complex - to indicate no simple panacea, and to end in a somewhat hopelessThere it is; what can we do? Both of these sorts of answers have something of truth in them: the Negro problem looked at in one way is but the old world questions of ignorance, poverty, crime, and the dislike of the stranger. On the other hand it is a mistake to think that attacking each of these questions singlehanded without reference to the others will settle the matter: a combination of social problems is far more than a matter of mere addition-the combination itself is a problem (p. 385).

Du Bois's admonishment underscores the link between our imagination of urban Black neighborhoods and their residents, and the impact that framework has on how 
we study and analyze such neighborhoods, people, and the social issues plaguing them. Essentially, what Du Bois is highlighting is that urban Black neighborhoods and residents provide a window into the complex intersections emergent in urban America. In his view, if we merely look to urban Black neighborhoods as an opportunity to expose social problems then we miss that such neighborhoods also reveal how such problems converge and get understood, manipulated, and communicated by urban residents. Indeed, the sociopolitical history of the Black Seventh Ward reveals that its residents actively shaped narratives about urban changes and the ways in which local and federal officials should address such issues associated with urban living, which brings us to the corrective aspect of this book.

Furthermore, Du Bois offers a perspective that centers racial history in ways that challenge (even today) extant frameworks regarding the importance of local economies and general market-driven logic for understanding the racial geography of the city and changes thereof. Similar to the assertions of others such as Park (1915), Ernest Burgess (1916, 1925), Michael Dear (2002), and Sharon Zukin (1995), Du Bois (1899) concedes that Philadelphia's economic center wields undeniable influence on urban residents and shares a proximal relationship with the overall population, observing that "it is clear that the nature of the Negro's work compels him to crowd in the centre of the city" (p. 296). Such similar conclusions notwithstanding, $\mathrm{Du}$ Bois also contends that the local economy alone did not provide sufficient explanation; hence the ecological conundrum he focuses upon throughout the book. Rather, Du Bois posits that although "the occupations which the Negro follow" make working and living "near the best portions of the city" (p. 296) necessary, Black agency and the city's lasting racial history have directly impacted the residential options for Blacks and Whites in Philadelphia.

Due to such factors, Du Bois (1899) finds that the spatial mobility of Blacks is fixed within a finite area of the city with other affluent districts in the city and the well-to-do suburbs along the city's main line remaining unavailable despite the comparable employment opportunities for Blacks therein. In The Philadelphia Negro, race, agency, and history operate as influential factors for understanding and analyzing urban America. In comparison to an almost exclusive market-driven logic posited by existing frameworks, Du Bois's urban approach also centers and uncovers the effects of the cultural and historical logic underpinning a city's physical and social landscape; thus Du Bois's approach shares explicit and implicit links with work that has examined, for example, the effects of racial residential segregation (Drake and Cayton, 1945; Gotham 2002; Hannerz 1969; Hirsch 1983; Massey and Denton, 1993; Silver and Moeser, 1995), urban racial violence and race relations (Anderson 1990; Charles 2006; Rhomberg 2004; Sugrue 1996), and rural-to-urban migration by southern Blacks during the Great Migration (Drake and Cayton, 1945; Gregory 2005; Lemann 1991; Wilkerson 2010).

Moreover, Du Bois's approach provides a framework that encompasses and is instructive for reading contemporary scholarship on urban poverty and the lasting effects of practices such as restrictive covenants and redlining, which targeted urban Blacks and has dramatically impacted the residential mobility of Blacks and Whites across cities (Pattillo-McCoy 1999; Perkins and Taylor, 1996; Sampson et al., 1997; Small 2004; Wilson 1987, 1996). Additionally, Du Bois's approach pioneered the historical perspective advocated by many who study cities such as Los Angeles. For instance, urban historians, notably Robert Fogelson (1993), have emphasized the influence that the social history of Los Angeles has on the fragmented local economy. In this way, Du Bois's approach sheds additional light on the importance of history for developing a sociological understanding of urban America. By highlighting the 
importance of Black agency, Du Bois's focus on the role of specific types of institutions, namely those that support the survival and success of marginalized groups, presages current arguments that point to the role of culture as an organizing force in urban spaces (Abrahamson 1996; Grazian 2003; Hannigan 1998; McRoberts 2003; Zukin 1989, 1991, 1995). In particular, Du Bois's querying of the ecological conundrum anticipates some of the challenges researchers would later discover as pertains to conventional urban ecological models.

Lastly, though Du Bois's illustration of Philadelphia as a series of neatly defined social spaces in the city is similar to a Chicago-based ecological model, Du Bois's contention that such enclaves maintain important and distinct racial attributes in addition to economic ones is a critical contrast. Much like existing approaches, Du Bois's also emphasizes the role of migration and the employment structure on the racial geography of the city. Whereas within traditional urban ecological models migration has been conceptualized as promoting processes of ethnic succession, whereby a natural transition between ethnic and racial groups occurs as individuals experience upward mobility (Park et al., 1925; Shaw and McKay, 1969), Du Bois reveals the important ways that racial history can predetermine the relationship that urban Black enclaves share with the neighboring economic core, thus delimiting urban spatial mobility. Indeed, critiques of existing approaches, particularly of the urban ecological approach, have contended that the relative importance of history is often absent or epistemologically undervalued (Dear 2002; Halle 2003; Orum and Chen, 2003). Du Bois's urban approach, then, both addresses and anticipates this gap, proffering a framework that bridges empirical and epistemological links between history and change and growth in urban America. Du Bois's observations, for example, link assertions made by scholars in later works on Chicago's symbolic communities (Hunter 1982), the segmentation of urban neighborhoods along racial and ethnic lines (Suttles 1970), and the persistent economic struggles for urban Blacks despite living in neighborhoods within close proximity to sites of employment (Anderson 1990; Pattillo 2007; Wilson 1987, 1996).

\section{CONCLUSION}

It was a hard job, but I completed it by the Spring of 1898 and published it a year later, under the auspices of the University, as The Philadelphia Negro; a formidable tome of nearly a thousand pages. -W. E. B. Du Bois, The Autobiography of W. E. B. Du Bois (1967, p. 198)

Over the last fifty years, scholars across disciplines have reexamined the work of W. E. B. Du Bois, pointing to myriad frameworks emergent in his work. Endeavoring to assert and uncover Du Bois's place as a central figure in sociology in particular, and the social sciences and humanities more generally, scholarship has centered on issues of race and racism (Aptheker 2000; Broderick 1974; Fields 2002; Hancock 2003; Marable 1986; Morris 2006; Morris and Ghazani, 2005; Rudwick 1974; Watts 1983; Young and Deskins, 2001; Zuckerman 2002). Of particular importance in the social sciences has been The Philadelphia Negro, as it perhaps stands as Du Bois's most comprehensive social scientific work.

The examination of The Philadelphia Negro provided here suggests that current interpretations of the text be broadened to encompass Du Bois's urban approach. Though others have noted Du Bois's connection with the works of Booth and the residents of the Hull House as impacting his methodology, the substantive connections between these works and The Philadelphia Negro must also be taken into account 
(Anderson 1999; Deegan 1988, 2002). To date, Du Bois's urban approach as presented in The Philadelphia Negro has not been fully explicated nor brought into dialogue with existing frameworks that focus on urban ecology, urban culture, and urban political economy (to name a few).

Within the existing literature, there are two principal readings of Du Bois's sociological imagination as evidenced in The Philadelphia Negro. According to one perspective, The Philadelphia Negro represents Du Bois's framework for understanding and analyzing issues of race and racism in the United States. The second major perspective centers on Du Bois's analysis of social class and his depiction of the Black community as heterogeneous. Unlike interpretations of major works by other figures in sociology, such as Parsons, Durkheim, and Weber (Camic 1987; Jones 1977, 1994), these perspectives are not in competition with one another, but rather reflect different emphases within the text and their relative importance.

Du Bois's discussion of race and racism has received the most attention from scholars. Most resonant in this perspective has been the final chapter of The Philadelphia Negro, wherein Du Bois provides a series of recommendations for uprooting the lasting and latent effects of racial oppression (McKee 1993; Morris 2006). Du Bois (1899) urges uneducated and undereducated Blacks to enhance their analytical and practical skills through increased schooling and also calls for the larger White community to acknowledge the direct ways in which racial prejudice and oppression have helped produce the negative outcomes for Blacks across rural and urban places. Particularly important is Du Bois's characterization of the social realities of Blacks in Philadelphia as a symptom of the larger system of racial discrimination by Whites (Bay 1998; Morris 2006; Rudwick 1974; Young and Deskins, 2001). Dissenting from conventional wisdom of the time which conceptualized the social realities of Blacks as related to an inherent inferiority, Du Bois, then, provided a novel and critical conception of the race problem (Morris 2006); such a characterization many have argued remained ignored well into the later half of the twentieth century (Bobo 2000; Morris 2006; Rudwick 1974; Young and Deskins, 2001; Zuberi 2004). Proponents of this perspective point to the lag in social scientific analyses and understandings of race, often to the detriment of the discipline.

Seeking to correct years of research and discourse in the social sciences that implicitly and explicitly operated within a framework that envisioned Blacks as inferior, lazy and/or uninterested in the betterment of the larger community, scholars have pointed to Du Bois's discussion in The Philadelphia Negro as counter to and more fruitful than dominant models for understanding and analyzing Black life (Bobo 2000; Morris 2006; Rudwick 1974; Wright 2000; Young and Deskins, 2001; Zuberi 2004). Du Bois's characterization of the race problem as a relational dynamic countered dominant models which suggested presumed biological differences between Black and Whites best explained racial disparities. Although this perspective rightly brings attention to Du Bois's conceptions of race and discussion of the effects of racism, a problematic aspect of this interpretation is that the larger reading of most of The Philadelphia Negro is developed through the lens of the final chapter. By foregrounding the interpretation of The Philadelphia Negro in this way, this perspective condenses Du Bois's analysis into one mostly concerned with the race problem and racism. This article, instead, examines The Philadelphia Negro in its entirety and thus offers a fuller elaboration of Du Bois's social scientific contribution in the book.

While less common than the attention to race and racism, considerable attention has focused on Du Bois's discussion of the class structure of the Black community. Critical to this scholarship is the four-tier model Du Bois uses to articulate the 
composition of the Black community. Du Bois (1899) proposes that four distinctive social and lifestyle classes characterized the Black population: 1) "the better class" or middle class; 2) the working class; 3 ) the poor; 4) and the criminal element (p. 31). With this typology, Du Bois offered an unprecedented discussion of how social class not only organized Black life but also determined social relations amongst Blacks, revealing the heterogeneity of the Black community (Anderson 2000; Bobo 2000; Booth 1900; Du Bois et al., 1978; Young and Deskins, 2001). Within this perspective scholars employ Du Bois's discussion of social class in The Philadelphia Negro to make connections with later important works by Drake and Cayton (1945), E. Franklin Frazier (1957) and Wilson (1987) among others who highlighted emerging trends in contemporary Black social class structure (Blackwell and Janowitz, 1974; Brueggemann 1997).

Such recent discoveries and debates notwithstanding, this article demonstrates that within The Philadelphia Negro Du Bois provides an urban approach that helps to examine and make sense of the ecological conundrum defining the social realities of residents both in 1896 (when he began his study) and now. In many ways, it is Du Bois's (1899) consideration of the physical and social environment, and his analysis of a "great city" and "its organic life" that highlight an additional and missed urban social scientific contribution of Du Bois and this major sociological work (p. 284). Du Bois makes clear that there is not only an emergent and continual impact of race and culture in urban America, but that these impacts shape cities in profound ways; thus setting the foundation for a tradition in urban social scientific research which values and employs history and culture as indispensable tools to examine urban America, especially when urban ecological and urban political-economic models are limited in their ability to fully analyze the ecological conundrum.

While diversity has come to characterize some cities, others still remain divided along racial and ethnic lines. Though others have shown that such a discussion by Du Bois demonstrates his anticipation of models of ethnic succession present in the urban ecological approach (Morris 2006; Wortham 2008), I extend these claims explicating Du Bois's attention to cultural and indigenous institutions. Specifically, Du Bois's urban framework illustrates how cultural and indigenous institutions, such as churches and schools, reinforce and influence existing patterns of urban racial geography, often sustaining the spatial mismatch between economic opportunity and the location of the "city within a city," the very crux of the ecological conundrum; thus Du Bois's approach also attends to the shifts in urban landscapes due to domestic migration within the United States, wherein such movement into cities does not lead to a succession of ethnic and racial communities, instead producing patterns of spatial and social isolation.

Ultimately, Du Bois's urban approach is one that acknowledges the importance and influence of the economic and political regimes of cities, while also affirming and asserting the importance of race, history, and Black agency. Moving the discussion of Du Bois, particularly as it pertains to a reading of The Philadelphia Negro, beyond his analysis of the "race problem" brings to the fore the key ideas about urban growth and change that undergird his empirical analysis; thus we are closer to fully employing the resources and ideas Du Bois's provides within and between the lines of The Philadelphia Negro. Explicating such Du Boisian ideas provides a significant intellectual and historical bridge and perspective for understanding and examining urban America.

Despite connections evident in existing scholarship, Du Bois's The Philadelphia Negro reveals that we must pay more attention to the interaction between Black agency and urban change and policy. While it is true that structural processes impact urban America, Du Bois demonstrates that an understanding of the full impact of 
such change remains incomplete without the inclusion and analysis of racial history and the agency of urban minorities. In this way, the movement and politics of urban Black residents have shaped American cities like Philadelphia.

Certainly The Philadelphia Negro emphasizes a point that many urban residents contend with daily, both then and now. That is, that most all American cities have a racial geography informed by a racial past. What is made clear for Du Bois in The Philadelphia Negro is that an examination of urban racial communities is key to understanding urban America as such communities are sociologically and historically rich reflections of why and how cities and their neighborhoods persist and change. Essentially, to add Du Bois's urban approach to our urban theorizing and discourse is to move closer to a more comprehensive picture of urbanity, and provide intellectual roots to branches of urban research that have come to similarly rely on the influence of history, race, and Black agency to understand and analyze urban America.

Corresponding author: Marcus Anthony Hunter, Department of Sociology, Yale University, P.O. Box 208265, New Haven, CT 06520-8265. E-mail: marcus.hunter@yale.edu

\section{NOTES}

1. The research presented in this article also benefited from the generous financial support of the American Sociological Association's Minority Fellowship Program, the National Science Foundation (Grant ID \#0902399), the Social Science Research Council, the Woodrow Wilson National Fellowship Foundation and the Mellon-Mays Undergraduate Fellowship Program. The author would like to thank and acknowledge Aldon Morris, Mary Pattillo, Charles Camic, Cathy J. Cohen, Jean Beaman, Rashida Z. Shaw, Mikaela Rabinowitz, Zandria Robinson, Christopher Wildeman, Gary Alan Fine, Dant'e Taylor, Elijah Anderson, Gerald Jaynes, Albert Hunter, Wendy Griswold, Edward Tiryakian, Hilary Silver, the Culture \& Society Workshop at Northwestern University, and the anonymous reviewers for their encouraging and constructive feedback.

2. Much like Jones (1977) in his reinterpretation of Durkheim's Elementary Forms, I acknowledge that in doing such a reinterpretation of a The Philadelpbia Negro implicit presentist preconceptions are somewhat unavoidable.

3. The goal of this discussion is meant to illustrate general dispositions of each of the existing approaches with respect to the racial geography of the city. For example, I am less concerned with the notion of Chicago, Los Angeles, and New York as schools, as such a focus is often more concerned with intellectual genealogy, brick and mortar institutions, and which cities are more representative of American urbanism. For a more detailed discussion about each of the schools as well as the intellectuals who might be imagined as operating within the paradigms each approach offers see Dear (2002), Halle (2003), Orum and Chen (2003), Clark (2006), and Hunter (2007). Instead, I focus on each as an urban theoretical approach with somewhat different frameworks regarding what is arguably a united concern across approaches-the racial geography of the city. It is not my intention to assert that the field of urban sociology is totally reducible to only this theme. We could just as easily think of the field as thematically situated around issues of political economy, place and space, community, and demograpby. For instance, Walton (1993) provides a great look into the work done on political economy in urban sociology in his review article. Wellman's (1979) discussion of the "community question" also demonstrates the larger importance of community as a central theme and source of inquiry in urban sociology.

4. Some notable exceptions include: Kelley (1996), Cohen (2010), and Hunter (2010).

5. According to the U.S. Census report from 2000, majority-minority cities whose population is predominantly Black included Detroit (83\%), Baltimore (65\%), Memphis (62\%), Washington, DC (61\%), and New Orleans $(67 \%)$. In that same year, Philadelphia's Black population accounted for $44 \%$ of its total population. For further details see Stoll (2004). 


\section{REFERENCES}

Abrahamson, Mark (1996). Urban Enclaves. New York: St. Martin's Press.

Anderson, Elijah (1990). Streetwise: Race, Class and Change in an Urban Community. Chicago, IL: University of Chicago Press.

Anderson, Elijah (1999). Code of the Street: Decency, Violence, and the Moral life of the Inner City. New York: W. W. Norton.

Anderson, Elijah (2000). The Emerging Philadelphia African American Class Structure. Annals of the American Academy of Political and Social Science, 568: 54-77.

Aptheker, Herbert (2000). Notes on Du Bois's Final Years. Souls, 4: 78-86.

Bay, Mia (1998). The World Was Thinking Wrong About Race. In Michael B. Katz and Thomas J. Sugrue (Eds.), W. E. B. Du Bois, Race, and the City: The Philadelphia Negro and Its Legacy, pp. 41-59. Philadelphia, PA: University of Pennsylvania Press.

Blackwell, James E. and Morris Janowitz (Eds.) (1974). Black Sociologists. Chicago, IL: University of Chicago Press.

Bobo, Lawrence (2000). Reclaiming a Du Boisian Perspective on Racial Attitudes. Annals of the American Academy of Political and Social Science, 568: 186-202.

Booth, Percy (1900). Review of The Philadelphia Negro. Annals of the American Academy of Political and Social Science, 15: 100-102.

Broderick, Francis L. (1974). W. E. B. Du Bois as Sociologist. In James E. Blackwell and Morris Janowitz (Eds.), Black Sociologists: Historical and Contemporary Perspectives, pp. 3-24. Chicago, IL: University of Chicago Press.

Brueggemann, John (1997). A Century After The Philadelphia Negro: Reflections on Urban Ethnography and Race in America. Fournal of Contemporary Ethnography, 26(3): 364-374.

Burgess, Ernest (1916). The Function of Socialization in Social Evolution. Chicago, IL: University of Chicago Press.

Burgess, Ernest (1925). The Growth of the City. In Robert Park, Ernest Burgess, and R.D. McKenzie (Eds.), The City, pp. 47-62. Chicago, IL: University of Chicago Press.

Camic, Charles (1987). The Making of a Method: A Historical Reinterpretation of the Early Parsons. American Sociological Review, 52(4): 421-439.

Charles, Camille Zubrinsky (2006). Won't You be My Neigbbor. New York: Russell Sage Foundation.

Clark, Terry N. (2006). The New Chicago School-Not New York or LA, and Why It Matters for Urban Social Science. In Richard P. Greene (Ed.), Chicago's Geographies: Metropolis for the 21st Century, pp. 242-258. Washington, DC: Association of American Geographers.

Cohen, Cathy J. (2010). Democracy Remixed. New York: Oxford University Press.

Dear, Michael (2002). Los Angeles and the Chicago School: Invitation to a Debate. City \& Community, 1(1): 5-32.

Deegan, Mary Jo (1988). W. E. B. Du Bois and the Women of the Hull-House, 1896-1899. American Sociologist, 19(4): 301-311.

Deegan, Mary Jo (2002). Race, Hull-House, and the University of Chicago. Westport, CT: Praeger.

Drake, St. Clair and Horace Cayton (1945). Black Metropolis: A Study of Negro Life in a Northern City. New York: Harcourt, Brace \& Company.

Du Bois, W. E. B. (1899). The Philadelphia Negro. Philadelphia, PA: The University of Pennsylvania.

Du Bois, W. E. B. (1903). The Souls of Black Folk. Chicago, IL: A.C. McClurg \& Co.; Cambridge, MA: University Press John Wilson and Son.

Du Bois, W.E. B. (1967). The Autobiography of W. E. B. Du Bois. Canada: International Publishers.

Du Bois, W. E. B., Dan S. Green, and Edwin D. Driver (1978). W. E. B. Du Bois On Sociology and the Black Community. Chicago, IL: University of Chicago Press.

Duneier, Mitchell (1999). Sidewalk. New York: Farrar, Strauss, and Giroux.

Fields, K. E. (2002). Individuality and the Intellectuals: An Imaginary Conversation between W. E. B. Du Bois and Emile Durkheim. Theory and Society, 31(4): 435-462.

Fogelson, Robert M. ([1967] 1993). The Fragmented Metropolis. Berkeley, CA: University of California Press.

Frazier, E. Franklin (1957). The Black Bourgeoisie. New York: The Free Press.

Gotham, Kevin Fox (2002). Race, Real Estate and Uneven Development. Albany, NY: State University of New York Press.

Grazian, David (2003). Blue Chicago: The Search for Authenticity in Urban Blues Clubs. Chicago, IL: University of Chicago Press.

Gregory, James N. (2005). The Southern Diaspora. Chapel Hill, NC: University of North Carolina Press. 
Gregory, Steven (1998). Black Corona. Chicago, IL: University of Chicago Press.

Halle, David (2003). New York \& Los Angeles: Politics, Society, and Culture. Chicago, IL: University of Chicago Press.

Hancock, Ange-Marie (2003). W. E. B. Du Bois: Intellectual Forefather of Intersectionality? Souls, 7: 60-68.

Hannerz, Ulf (1969). Soulside. Chicago, IL: University of Chicago Press.

Hannigan, John (1998). Fantasy City: Pleasure and Profit in the Postmodern Metropolis. New York: Routledge.

Hirsch, Arnold (1983). Making the Second Ghetto. Chicago, IL: University of Chicago Press.

Hunter, Albert (1982). Symbolic Communities: The Persistence and Change of Chicago's Local Communities. Chicago, IL: University of Chicago Press.

Hunter, Marcus Anthony (2007). Ecologies, Post-Modern Urbanisms, and Symbolic Economies: American Urban Sociology and the City. Unpublished Special Fields Paper, Department of Sociology, Northwestern University.

Hunter, Marcus Anthony (2010). The Nightly Round: Space, Social Capital, and Urban Black Nightlife. City \& Community, 9(2): 165-186.

Hunter, Marcus Anthony (2013). Black Citymakers: How The Philadelphia Negro Changed Urban America. New York: Oxford University Press.

Jones, Robert A. (1977). On Understanding a Sociological Classic. The American fournal of Sociology, 83(2): 279-319.

Jones, Robert A. (1994). Ambivalent Cartesians: Durkheim, Montesquieu, and Method. American Fournal of Sociology, 100(1): 1-39.

Katz, Michael and Thomas Sugrue (1998). W. E. B. Du Bois, Race, and the City: The Philadelphia Negro and the City. Philadelphia, PA: University of Pennsylvania Press.

Kelley, Robin D.G. (1996). Race Rebels. New York: Free Press.

Lacy, Karyn (2007). Blue-Chip Black. Berkeley, CA: University of California Press.

Lamont, Michele and Virag Molnár (2002). The Study of Boundaries in the Social Sciences. Annual Review of Sociology, 28: 167-195.

Lemann, Nicolas (1991). The Promised Land. New York: Random House.

Lewis, David Levering (1993). W. E. B. Du Bois. New York: Holt.

Marable, Manning (1986). W. E. B. Du Bois: Black Radical Democrat. Boston, MA: Twayne.

Massey, Douglas and Nancy Denton (1993). American Apartheid. Cambridge, MA: Harvard University Press.

McKee, James (1993). Sociology and the Race Problem: The Failure of a Perspective. Urbana, IL: University of Illinois Press.

McRoberts, Omar (2003). Streets of Glory. Chicago, IL: University of Chicago Press.

Morris, Aldon (2006). American Sociology of Race and the Ignoring of W. E. B Du Bois: The Price of the Path Not Taken. In Craig Calhoun (Ed.), Sociology in America: The ASA Centennial History, pp. 503-534. Chicago, IL: University of Chicago Press.

Morris, Aldon and Amin Ghazani (2005). Du Boisian Sociology: A Watershed of Professional and Public Sociology. Souls, 7: 47-54.

O'Connor, Shannon (2009). Methodological Triangulation and the Social Studies of Charles Booth, Jane Addams, and W. E. B. Du Bois. Sociation Today, 7 (1). 〈http://www.ncsociology .org/sociationtoday/v71/three.htm $\rangle$ (accessed November 1, 2010).

Orum, Anthony M. and Xianming Chen (2003). The World of Cities: Places in Comparative and Historical Perspective. Oxford, UK: Blackwell Publishing.

Park, Robert E. (1915). The City: Suggestions for the Investigation of Human Behavior in the City Environment. American Fournal of Sociology, 20(5): 577-612.

Park, Robert E. (1983). Human Ecology. Reprinted in Roland Warren and Larry Lyon (Eds.), New Perspectives on the American Community, pp. 26-33. Homewood, IL: Dorsey Press.

Park, Robert E., Ernest Burgess, and R. McKenzie (1925). The City. Chicago, IL: University of Chicago Press.

Pattillo, Mary (2007). Black on the Block: The Politics of Race and Class in the City. Chicago, IL: University of Chicago Press.

Pattillo-McCoy, Mary (1999). Black Picket Fences: Privilege and Peril Among the Black Middle Class. Chicago, IL: University of Chicago Press.

Perkins, D. D. and R. B. Taylor (1996). Ecological Assessments of Community Disorder. Annual fournal of Community Psychology, 24: 63-107.

Reed, Adolph L. (1999). Stirrings in the fug: Black Politics in the Post-segregation Era. Minneapolis, MN: University of Minnesota Press.

Rhomberg, Chris (2004). No There There. Berkeley, CA: University of California Press. 
Rudwick, E. (1974). W. E. B. Du Bois as Sociologist. In James E. Blackwell and Morris Janowitz (Eds.), Black Sociologists: Historical and Contemporary Perspectives, pp. 25-55. Chicago, IL: University of Chicago Press.

Sampson, Robert, Stephen Raudenbush, and Felton Earls (1997). Neighborhoods and Violent Crime: A Multilevel Study of Collective Efficacy. American Fournal of Public Health, 95: $225-232$.

Shaw, Clifford R. and Henry D. McKay ([1942] 1969). Fuvenile Delinquency and Urban Areas. Chicago, IL: University of Chicago Press.

Silver, Christopher and John V. Moeser (1995). The Separate City: Black Communities in the Urban South, 1940-1968. Lexington, KY: University of Kentucky Press.

Small, Mario (2004). Villa Victoria: The Transformation of Social Capital in a Boston Barrio. Chicago, IL: University of Chicago Press.

Stack, Carol B. (1974). All or Kin: Strategies for Survival in a Black Community. New York: Harper \& Row Publishers.

Stoll, Michael A. (2004). The American People Census 2000: African Americans and the Color Line. New York: Russell Sage Foundation.

Sugrue, Thomas (1996). The Origins of Urban Crisis. Princeton, NJ: Princeton University Press.

Suttles, Gerald (1970). The Social Order of the Slum. Chicago, IL: University of Chicago Press.

Venkatesh, Sudhir A. (1999). American Project. Cambridge, MA: Harvard University Press.

Venkatesh, Sudhir A. (2006). Off the Books. Cambridge, MA: Harvard University Press.

Walton, John (1993). Urban Sociology: Contributions and Limits of Political Economy. Annual Review of Sociology, 19: 301-320.

Watts, J. G. (1983). On Reconsidering Park, Johnson, Du Bois, Frazier and Reid: Reply to Benjamin Bowser's 'The Contribution of Blacks to Sociological Knowledge.' Phylon, 4: 273-291.

Weger, Stacey (2009). The Berlin Years: The Influence of German Thought and Experience on the Development of Du Bois' Sociology. Sociation Today, 7(1). 〈http://www.ncsociology.org /sociationtoday/v71/berlin.htm $\rangle$ (accessed November 1, 2010).

Wellman, Barry (1979). The Community Question: The Intimate Networks of East Yorkers. American fournal of Sociology, 84(5): 1201-1231.

Wilkerson, Isabel (2010). The Warmth of Other Suns. New York: Random House.

Wilson, William Julius (1987). The Truly Disadvantaged. Chicago, IL: University of Chicago Press.

Wilson, William Julius (1996). When Work Disappears: The World of the New Urban Poor. New York: Random House.

Wilson, William Julius and Richard P. Taub (2006). There Goes the Neighborhood. New York: Vintage.

Wortham, Robert (2008). W. E. B. Du Bois' Urban Sociology: Reflections on African American Quality of Life in Philadelphia. Sociation Today, 6(1). 〈http://www.ncsociology.org /sociationtoday/v61/dubois2.htm $\rangle$ (accessed November 1, 2010).

Wortham, Robert (2009). W. E. B. Du Bois and Demography: Early Explorations. Sociation Today, 7 (1). 〈http://www.ncsociology.org/sociationtoday/v71/phila.htm〉 (accessed November 1, 2010).

Wright, Earl (2000). Atlanta University and American Sociology, 1896-1917: An Earnest Desire for Truth Despite its Possible Unpleasantness. PhD Dissertation, Department of Sociology, University of Nebraska.

Young, Alford, Jr. and Donald Deskins, Jr. (2001). Early Traditions of African-American Sociological Thought. Annual Review of Sociology, 27: 445-477.

Zorbaugh, Harvey W. (1929). The Gold Coast and the Slum. Chicago, IL: University of Chicago Press.

Zuberi, Tukufu (2004). W. E. B. Du Bois's Sociology: The Philadelphia Negro and Social Science. Annals of the American Academy of Political and Social Science, 559: 146-156.

Zuckerman, Phil (2002). The Sociology of Religion of W. E. B. Du Bois. Sociology of Religion, 63(2): 239-253.

Zukin, Sharon (1989). Loft Living: Culture and Capital in Urban Change. New Brunswick, NJ: Rutgers University Press.

Zukin, Sharon (1991). Landscapes of Power: From Detroit to Disney World. Berkeley and Los Angeles, CA: University of California Press.

Zukin, Sharon (1995). Culture of Cities. Oxford, UK: Blackwell Publishing. 